\title{
AUTOMATED STORAGE AND RETRIEVAL SYSTEM AN ALTERNATIVE FOR LOGISTIC TRANSFORMATION TECHNOLOGY: A CASE STUDY
}

\author{
Adi Saptari"1, a , Ardhi Bebi Laksono ${ }^{2, b}$ \\ 1,2 Master of Management and Technology Study Program, Faculty of Management, President \\ University Jl. Ki Hajar Dewantara, Jababeka Education Park, Bekasi, 17550, Indonesia Indonesia \\ a adi.saptari@president.ac.id, bardhi.bebi.laksono@gmail.com
}

\begin{abstract}
Abstrak.
Penelitian ini dilakukan pada salah satu perusahaan teknik mesin yang memproduksi suku cadang, mesin khusus, integrator sistem otomasi dan instalasi robotik. Perusahaan memiliki masalah biaya operasi gudang yang tinggi, kebutuhan ruang untuk memperluas lini produksi, masalah stock opname, kegagalan pengambilan, waktu siklus operasi yang tinggi, efisiensi logistik, dan biaya persediaan. Permasalahan tersebut berdampak pada kinerja perusahaan yang membutuhkan penurunan ongkos, peningkatan efisiensi dan produktivitas dengan defect yang minimal. Data menunjukkan perusahaan membutuhkan tambahan $157 \mathrm{~m} 2$ untuk memperluas warehouse, kesalahan dalam pengambilan (retrieving) 4\%, biaya operasional 200 juta lebih, waktu siklus 150 detik, $7 \%$ parts yang hilang dan risiko keamanan data cyber. Mengingat pentingnya masalah tersebut, maka perusahaan perlu mengevaluasi dan memecahkan masalah yang berdampak pada kinerja perusahaan, khususnya di bagian gudang. Pendekatan DMAIC (Define Measure Analyze Improve and Control) diterapkan untuk mengeksplorasi masalah secara komprehensif dan menghasilkan alternatif solusi. Dua alternatif dikembangkan. Kriteria pemilihan yang digunakan adalah biaya; akurasi, keamanan, keselamatan, produktivitas, waktu siklus, dan meminimalkan cacat Disimpulkan bahwa penerapan sistem penyimpanan dan pengambilan otomatis (ASRS) dipilih karena mendominasi dalam banyak aspek dibandingkan dengan memperluas gudang yang sekarang. Implementasi ASRS ini menunjukan bahwa sistem baru ini menjawab masalah gudang saat ini.
\end{abstract}

Kata kunci. ASRS, otomasi gudang, dmaic, kriteria, seleksi.

\begin{abstract}
.
This research was taken at one of the mechanical engineering companies produces customize spare parts, special purposed machinery, automation system integrator and robotic installation. The company has problem high cost operation warehouse, need space expanding production line, stockopname problem, picking failure, high cycle time operation, logistic efficiency, and inventory cost. These problems have impact to company performance which need cost down, increase efficiency and productivity with minimum defect. The data has shown company needs additional $157 \mathrm{~m} 2$ to expanding new line, has $4 \%$ picking defect, there is 200 million operational cost over, $150 \mathrm{sec}$ cycle time, $7 \%$ lost part and risk cyber data security. Due to the importance of the problem, the company needs to evaluate and solve the problem which has impact to company performance, especially in the warehouse. DMAIC (Define Measure Analyze Improve and Control) approach is applied to comprehensively explore the problem and comes out with alternatives solution. Two alternatives were developed. The criteria for selection used were i.e. cost; accuracy, security, safety, productivity, cycle time, and minimize defect It was concluded that the application of automated storage and retrieval system (ASRS) was selected as it dominates in many aspects compare to expanding the current one. This implementation of ASRS approved that this new system answers the current warehouse problem
\end{abstract}

Keywords: ASRS, warehouse automation, DMAIC, criteria, selection. 
Indonesia is one of the most strategic manufacturing industries and has contributed significantly to the development of the Indonesian economy by increasing the scale of exports and absorbing large numbers of workers with a total of 1.5 million workers in 2020. This study was conducted in one of the local supplier manufacturing industries. Due to the growing in business, this industry needs to be supported from all parts of the industry. Warehouse is part of a process in business that provides a very important role. Warehousing can provide significant benefits if it meets adequate infrastructure and applies the right methods.

The company was founded in 1994 with specializing in producing various custom made special purpose machines (SPM), automation system integrator and robotic installation. This study was to identify the parameter that causing a major problem in the warehouse operations. In order to capture with the development of the business, the company needs to respond quickly to facilitate the operations activities. Starting the business issue then identify and validate, then draft the problem statement. In 2021, due to the increasing inventory to manage, and the business growth prospects, the company needs a new facility, more technological and innovative, more in line with the company's positioning and the brands distributed. It can be noticed that in 2015 the revenue reached Rp. 78 billion and in 2020 this number increase to Rp. 201billion, which means increase in average Rp. 24.6 billion or in average increase $31 \%$ yearly..

\section{Research Method}

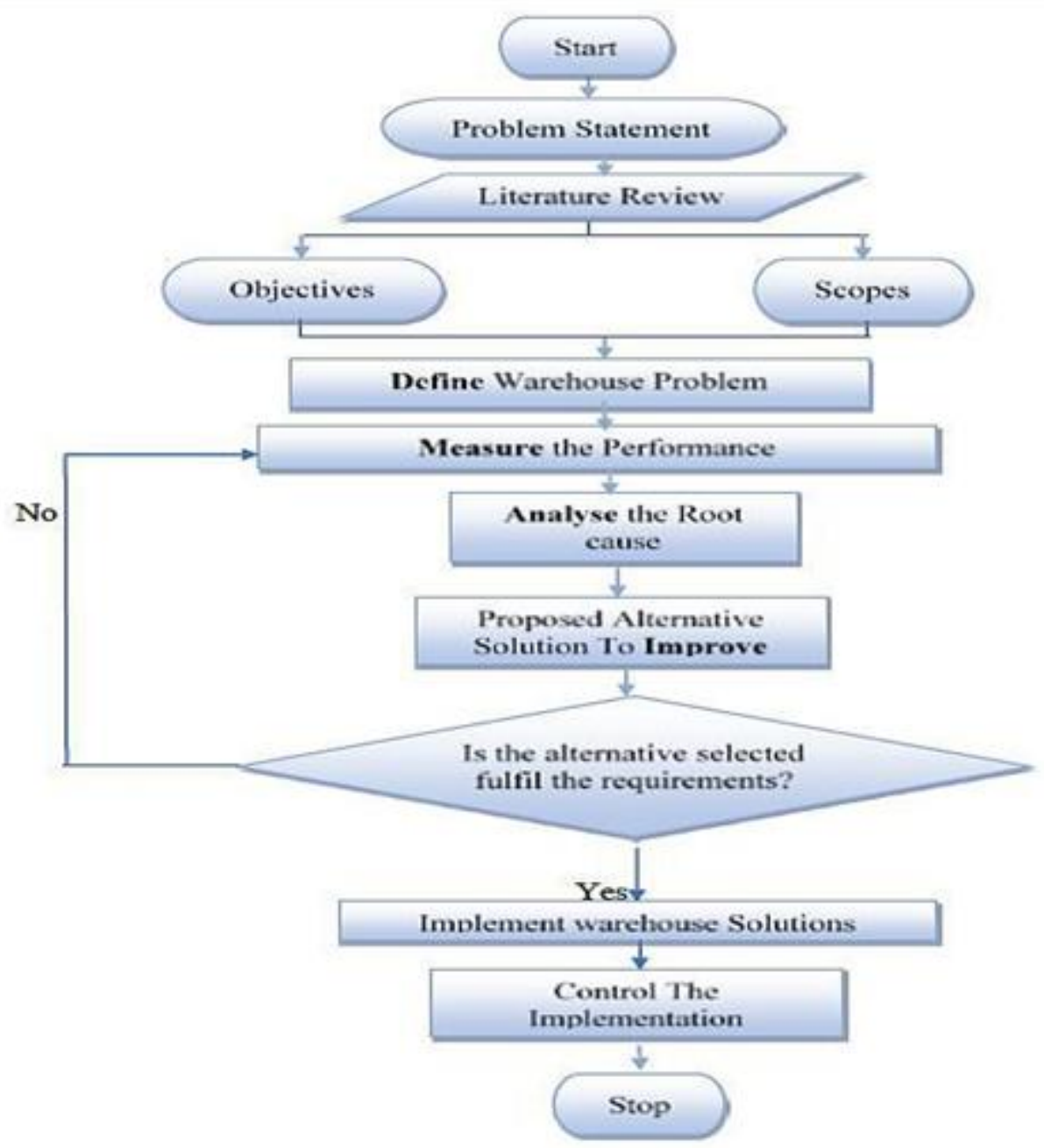

Figure 1. Flowchart Process Method

This research is a case study in the company which facing a problem in the warehouse. The activities of the company have expanded and needs a larger warehouse to support its activities. An analysis of 
the root caused is necessary also the alternative solution that possible to be implemented and proposed some recommendation for solution. The planning of the study shows in Figure 1 The flowchart depicts the steps to carry out the study.

\section{PROBLEM DEFINITION (D)}

Warehouses, nowadays, are increasingly under pressure due to labour scarcity and costly floor space, as well as to ensure accurate order deliveries. With the rising demand for automation, automated storage and retrieval systems are being established as one of the most versatile solutions for material handling processes. ASRS is a material handling equipment, which is widely used in manufacturing plants, warehouses, and distribution centres. ASRS offers enhanced inventory control and tracking, reduces labour costs, increases workplace safety, minimizes accidents during product handling, improves efficiency of plant and distribution centres, reduces the possibility of damages to products, and decreases the overall cost of supply chain processes.

Table 1. Indicators of Warehouse Operations Problem in The company

\begin{tabular}{|c|c|c|}
\hline No & Indicators & Description \\
\hline 1 & $\begin{array}{l}\text { Uncontrolled } \\
\text { Operational cost } \\
\text { of warehouse }\end{array}$ & $\begin{array}{l}\text { Uncontrolled Operational Cost of the warehouse has reach } \mathrm{Rp} \\
2,354,400,000 / \text { year. This number is considered big }\end{array}$ \\
\hline 2 & Accuracy & $\begin{array}{l}\text { According to the initial survey it was identified that incorrect items return } \\
\text { reach } 480 \text { parts in } 2020 \text { or approximately } 4 \% \text { of the total activities. This } \\
\text { number is considerable high, it may cause customer dissatisfaction and } \\
\text { high cost of warehouse. }\end{array}$ \\
\hline 3 & Security & $\begin{array}{l}\text { The record of part loss during year } 2020 \text { was } 1,498 \text { unit of part or } 0.04 \% \\
\text { from the available parts. This is showing the performance of security in } \\
\text { terms of item losses per unit of time is alarming. }\end{array}$ \\
\hline 4 & Safety & $\begin{array}{l}\text { The current warehouse systems prone to accidents. The activities of } \\
\text { storing and retrieving of parts are still using the existing equipment. The } \\
\text { number of cases of accidents happened in the current systems reach } 2 \\
\text { workers are falling items and } 4 \text { persons getting stuck. }\end{array}$ \\
\hline 5 & $\begin{array}{l}\text { Productivity } \\
\text { (Output vs } \\
\text { Input) }\end{array}$ & $\begin{array}{l}\text { Productivity status of warehouse in rough can be seen from the number } \\
\text { of workers in the warehouse currently reach } 30 \text { operators. Whereas the } \\
\text { activities per day in the warehouse is } 9,200 \text { order. So, Number of orders } \\
\text { per day divided by the number of workers in rough reach } 306 \text { In terms of } \\
\text { cycle time of retrieving parts is indicated } 150 \text { second consist of } 60 \text { second } \\
\text { for putting the parts and } 90 \text { second for unloading. In the operations it was } \\
\text { defined there some Non-value added actives. }\end{array}$ \\
\hline
\end{tabular}




\section{Accuracy}

\section{MEASURE (M)}

To calculate the KPI's order-taking accuracy, the total number of orders and subtract the number of incorrect returns. Then that result is divided by the total number of orders, and multiplied by 100 (for a percentage). According to Frazelle (2002) to calculate order accuracy can use the formula:

Table 2. Accuracy Picking Order Data

\begin{tabular}{|clccc|}
\hline No & Month & $\begin{array}{c}\text { Total } \\
\text { Orders }\end{array}$ & $\begin{array}{c}\text { Incorrect } \\
\text { Item } \\
\text { Returns }\end{array}$ & $\begin{array}{c}\text { Order } \\
\text { Picking } \\
\text { Accuracy }\end{array}$ \\
\hline $\mathbf{1}$ & January & 1300 & 80 & $94 \%$ \\
\hline $\mathbf{2}$ & February & 700 & 40 & $94 \%$ \\
\hline $\mathbf{3}$ & March & 890 & 60 & $93 \%$ \\
\hline $\mathbf{4}$ & April & 665 & 50 & $92 \%$ \\
\hline $\mathbf{5}$ & May & 1267 & 10 & $99 \%$ \\
\hline $\mathbf{6}$ & June & 1435 & 0 & $100 \%$ \\
\hline $\mathbf{7}$ & July & 1650 & 70 & $96 \%$ \\
\hline $\mathbf{8}$ & August & 997 & 0 & $100 \%$ \\
\hline $\mathbf{9}$ & September & 879 & 0 & $100 \%$ \\
\hline $\mathbf{1 0}$ & October & 1339 & 50 & $96 \%$ \\
\hline $\mathbf{1 1}$ & November & 1490 & 40 & $97 \%$ \\
\hline $\mathbf{1 2}$ & December & 1450 & 80 & $94 \%$ \\
\hline & Total & $\mathbf{1 4 , 0 6 2}$ & $\mathbf{4 8 0}$ & $\mathbf{4 \%}$ \\
\hline
\end{tabular}

\section{Worker and Cycle Time}
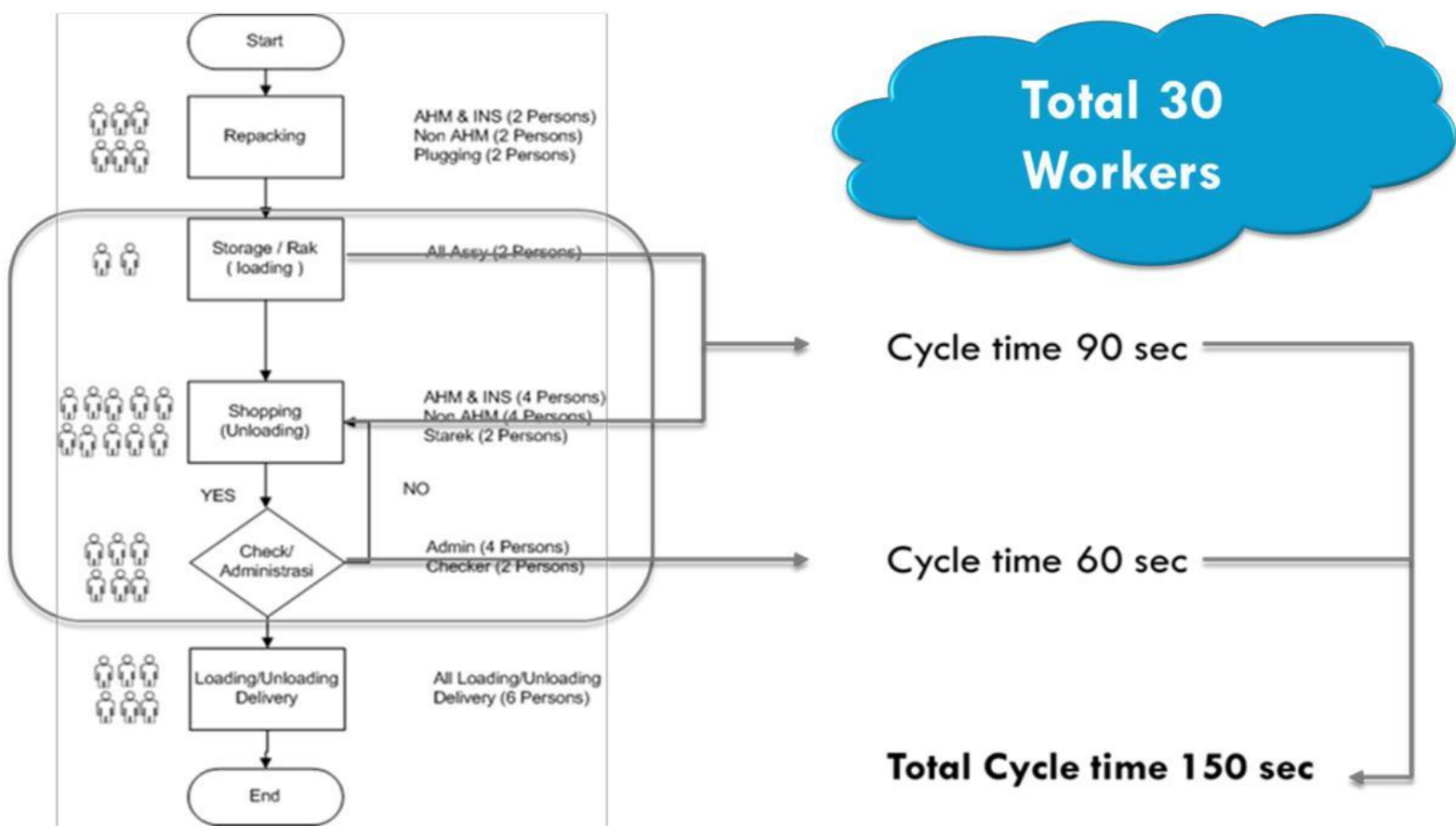

Cycle time $90 \mathrm{sec}$

Cycle time $60 \mathrm{sec}$

Total Cycle time $150 \mathrm{sec}$

Figure 2. Worker and Cycle Time Data 
In this case, the analysis method as below is used to find out work activities that do not provide added value to the company. The goal is to identify, and then eliminate, those parts of the operation that provide costs but do not add value.

\section{Warehouse Performance (Value and Non-Value-Added Activities)}

In retrieving process, the work elements are basically categorized into value-added and non-value added. Value added (VA) is work that valuable and necessary to be done in order to complete the tasks.

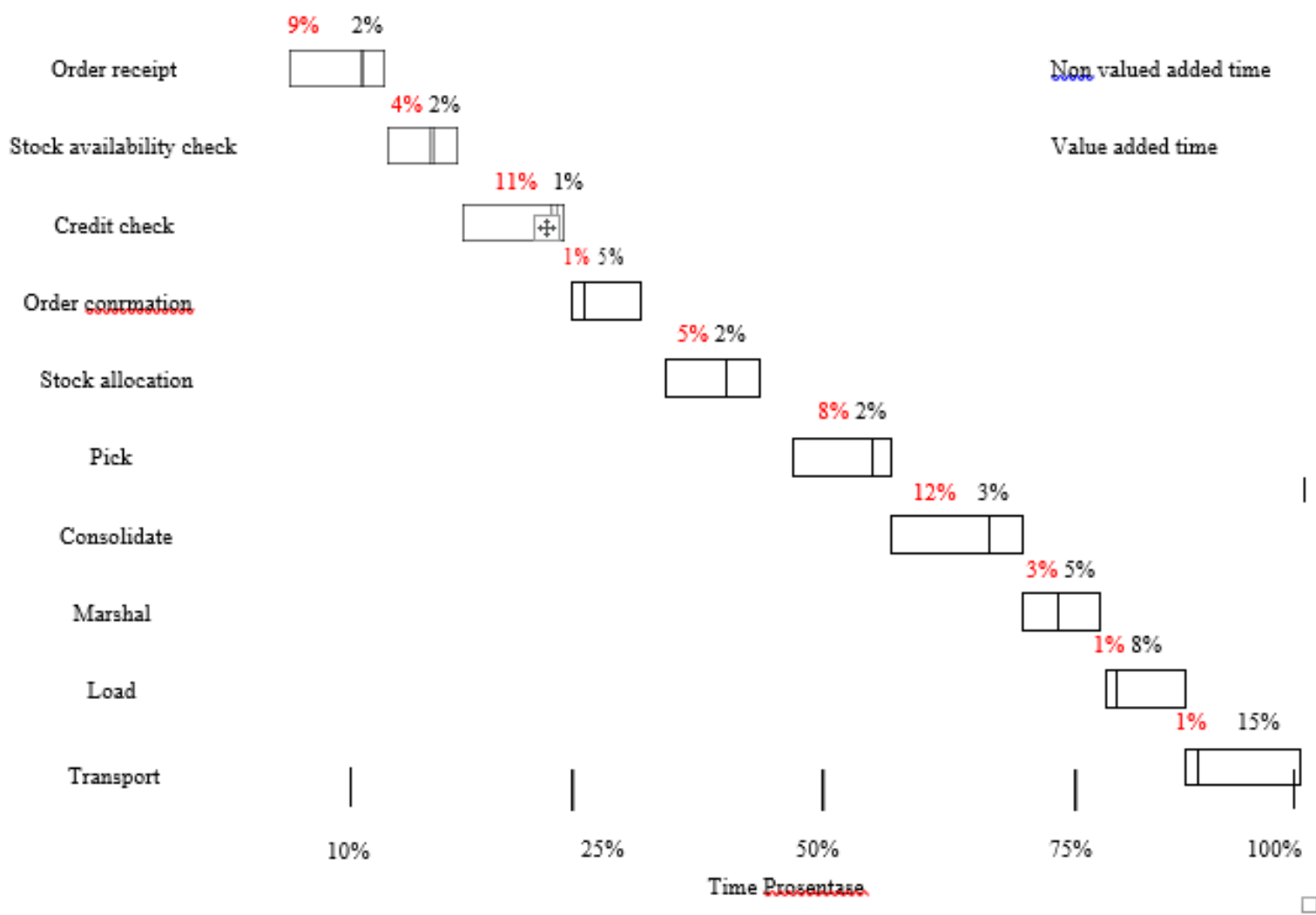

Figure 3. Value Added and Non-value Added Data

\section{Safety and Security}

Based on research conducted on risk analysis in the warehouse area, it can be concluded that some potential accident could be happen due to some situation such as follows:

- $\quad$ Total accident report at the company: 2 cases are falling item and 4 cases getting stuck.

\begin{tabular}{|rrrcc|}
\hline & Data System & Data Actual & Part Losses & Accuracy \\
\hline Total & $3,994,053$ & $3,992,556$ & 1,498 & $0.04 \%$ \\
\hline
\end{tabular}

\section{Space Area}

The main problem to be solved was the optimization of the available storage space in order to increase space. The firm wants to maximize the use of available space, to increase storage capacity, free up room for production with innovative high-density space-saving solutions. 


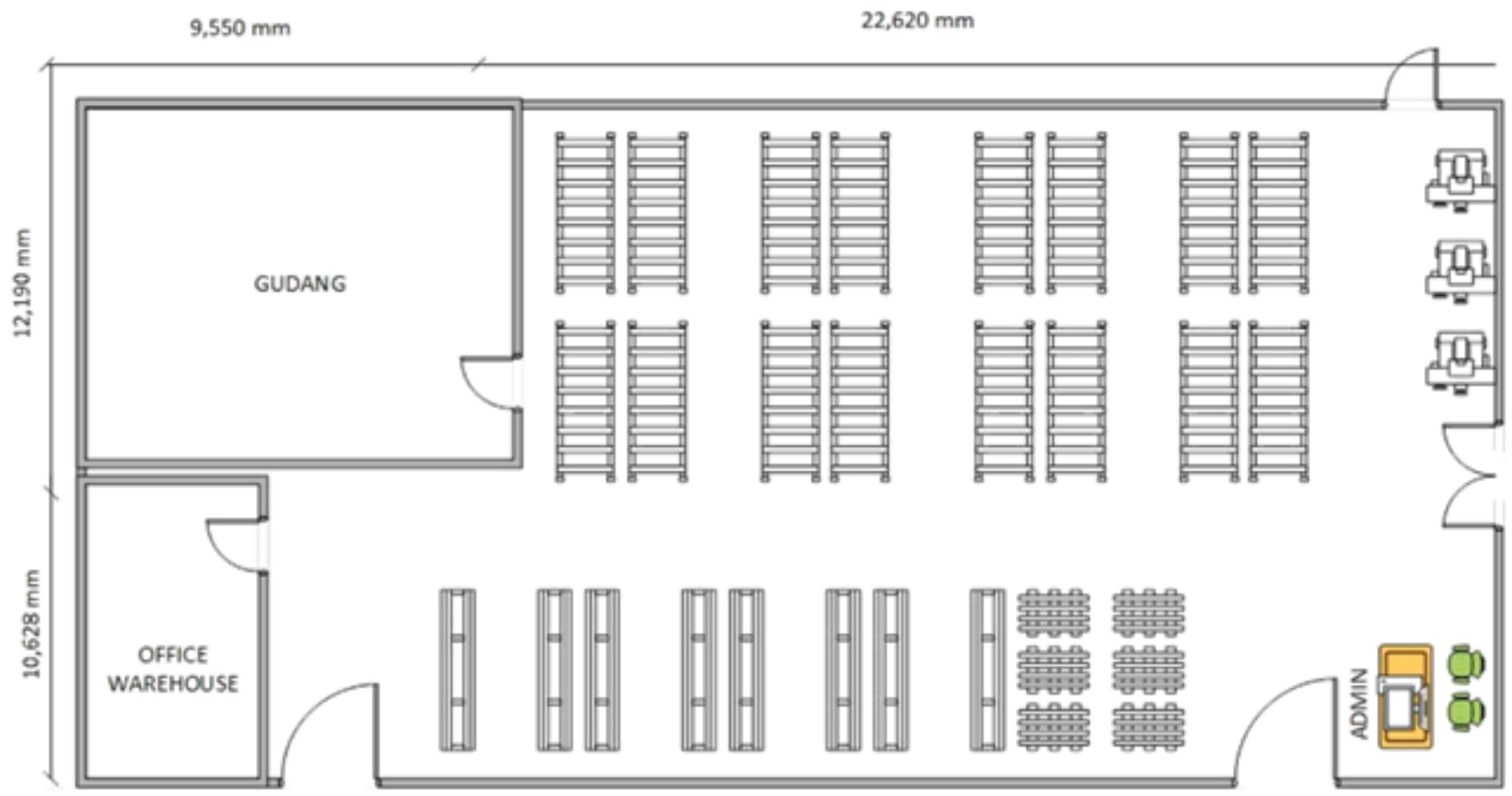

Figure 4. Layout Data

ANALYSES PHASE (A)

Fishbone diagram in analyses phase is crucial to choose the relevant information from the summary data to ensure the right data is collected and useful for the research. Fishbone diagram showed in Figure 5 after brainstorming with team members to identify the potential root causes that contribute to problem in warehouse operations.

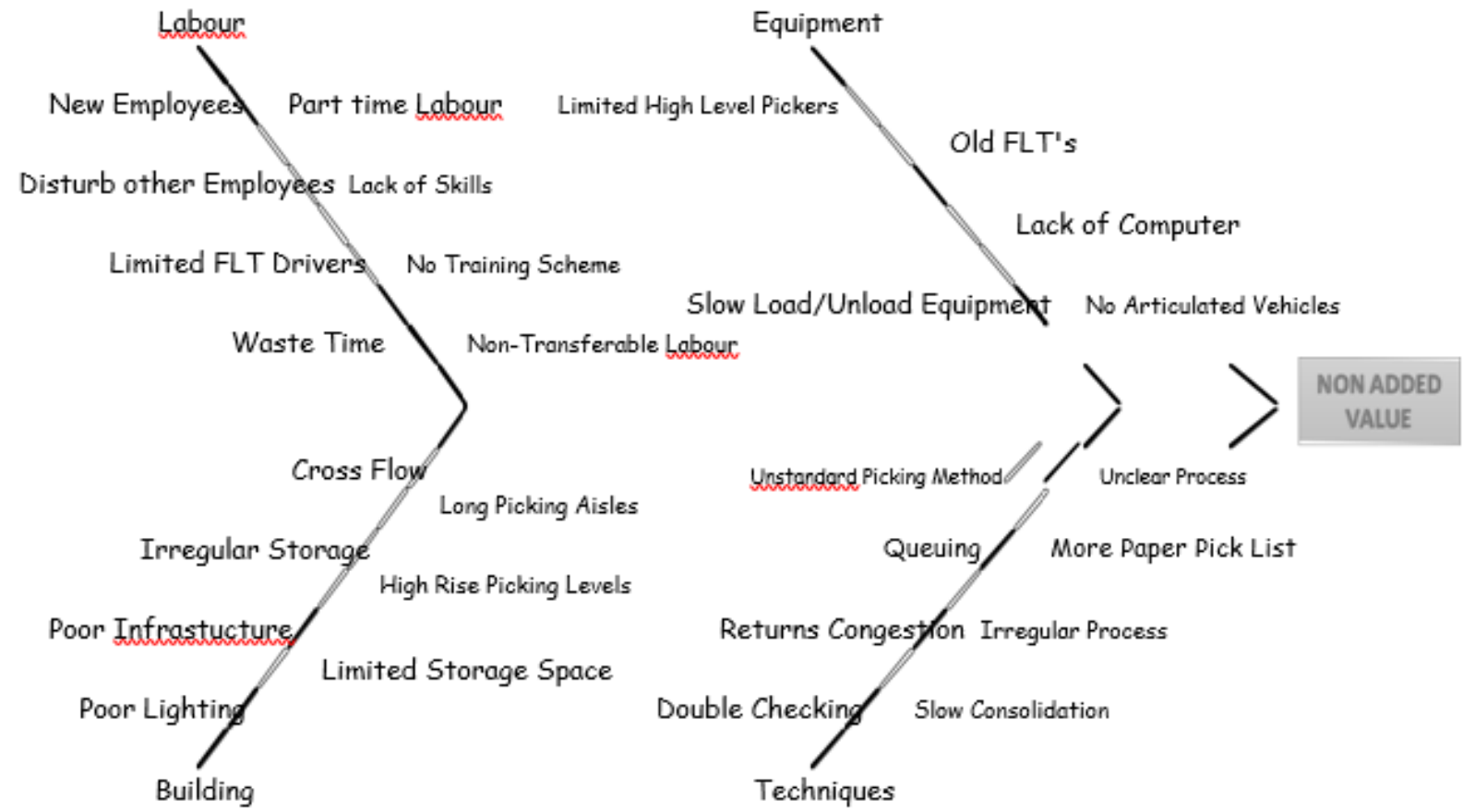

Figure 5. Fish Bone Diagram of Warehouse Problem 


\section{IMPROVEMENT (I)}

\section{Alternative \#1}

To support the alternative\#1, additional building is necessary to back up the activities. It was identified the number of area needed and the cost of rental building. The area needed approximately $250 \mathrm{~m} 2$. The available rental building according to the market in Cikarang area cost Rp. $840,000 / \mathrm{m} 2$

$=840,000 /^{2}$

$$
\begin{array}{rr}
= & 275^{2} 840,000 /{ }^{2}=231,588,000 \\
& =22,4^{2} 840,000 /{ }^{2}=18,772,000 \\
=\quad 231,588,000-18,772,000=212,772,000 &
\end{array}
$$

Additional facilities needed to maintain the facilities; this cost is approximately $\mathrm{Rp} 3,200,000,000$

\section{Alternative \#2}

This alternative applies a new technology of warehousing systems. The technology available that fits with the requirements of current operations and available land and building of the facilities is ASRS (Automated Storage Retrieval Systems). This system also applis IoT (internet of things), and new features of information technology.

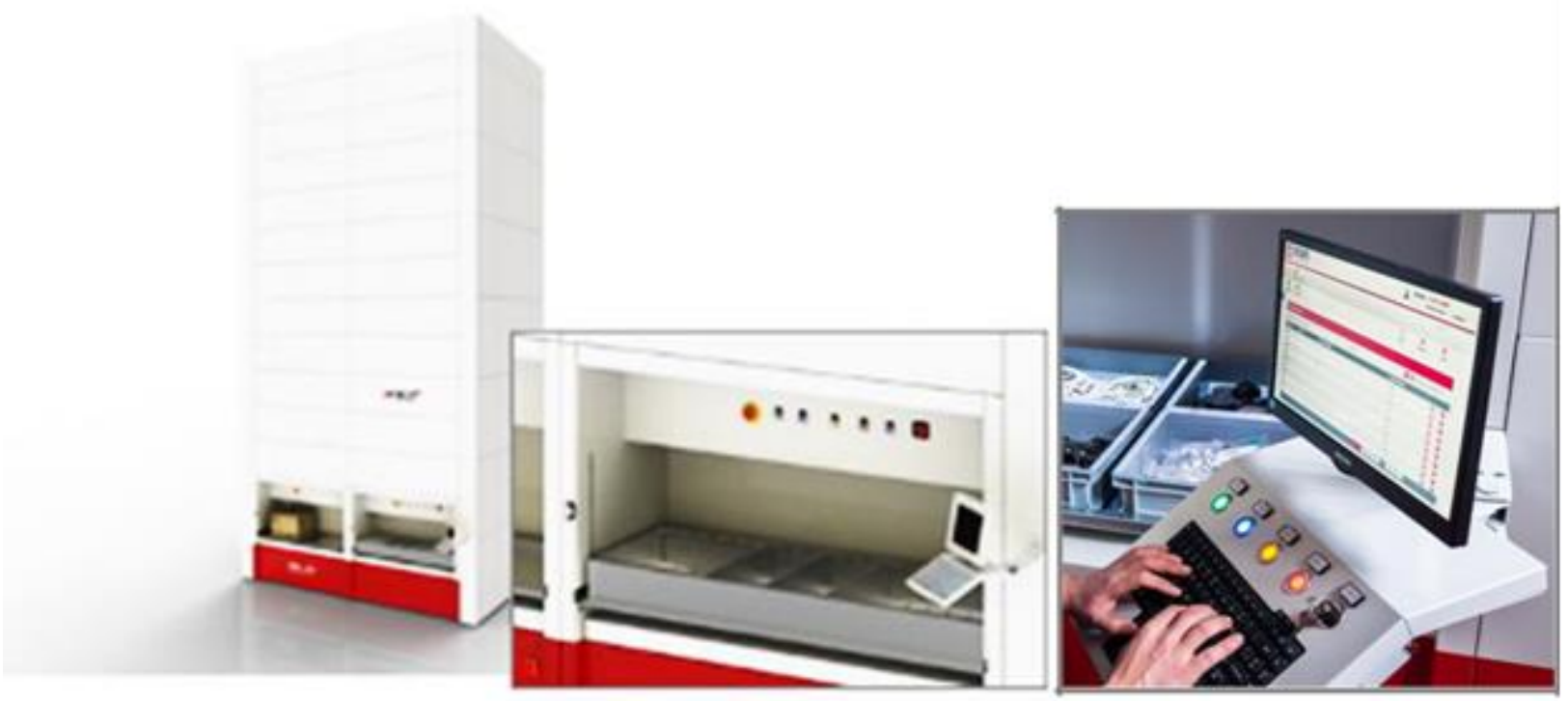

Figure 6. Automated Storage and Retrieval System

\section{Worker \& Cycle Time}

The advantages are the items can be attached on the storage a lot more and the space can be reduced. The ASRS proposed two man power to allocated for situation with high or low. With ASRS installed system, a flexible allocation manpower plan can be implemented in order to handle a different kind of production capacity. The firm proposed two kind of manpower allocation table for a situation with high loading activity and a low loading one. With the all item that, The firm calculate the tray needed, in order to a handle fast moving production item priority in ASRS. So, the number of workers save for the migration of current systems to ASRS will 12 operators which may be allocated to other productive sections in the organization. Figure above shows two systems, the current one which is ASRS system. The figure indicates the number of operators involved in activating the systems. 


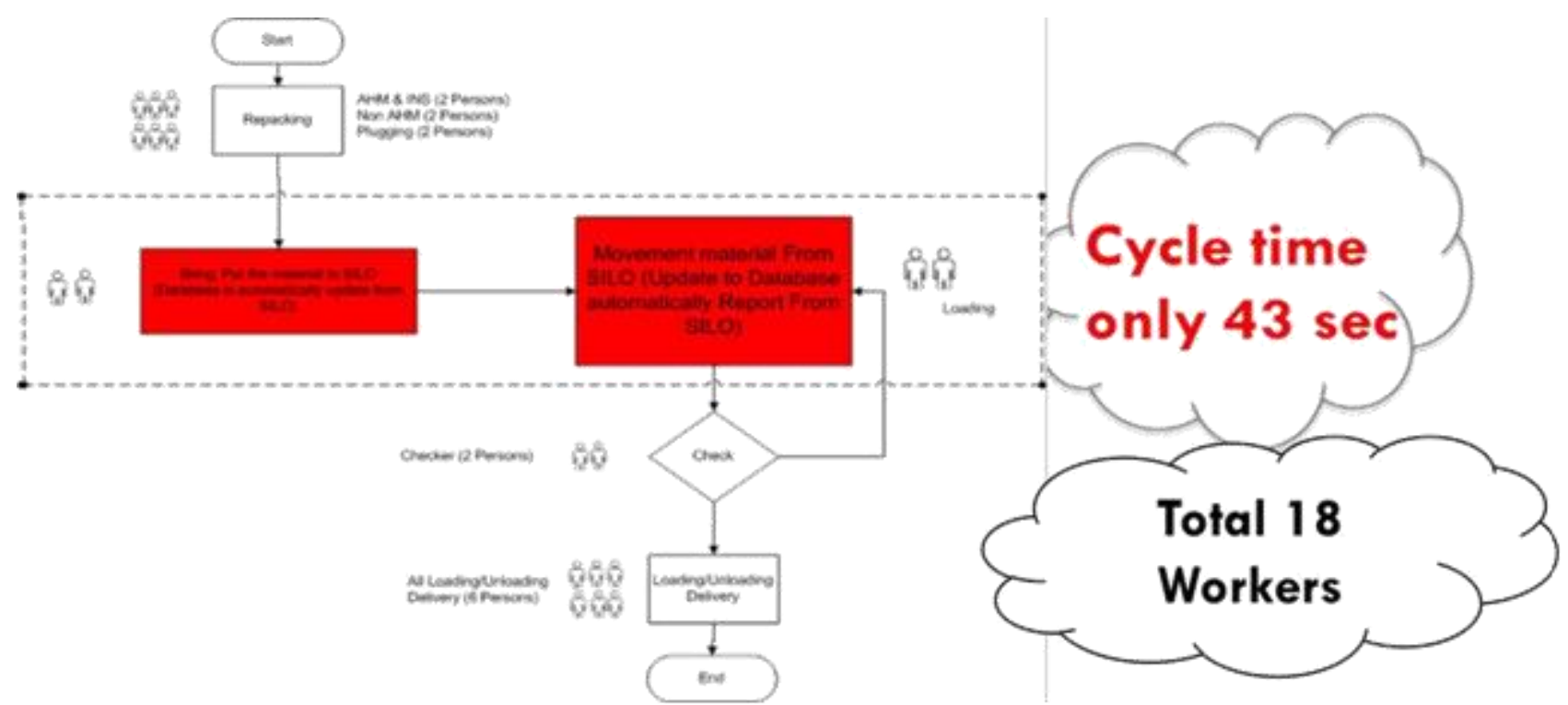

Figure 7. Worker \& Cycle Time after Improvement

The illustration Figure 7 illustrates a significant decrease in the number of manpower, this means that the company is able to reduce the cost of manpower.

Table 3. Summary of manpower after installation

$\begin{array}{lccc}\text { Job Responsibility } & \begin{array}{c}\text { Worker } \\ \text { Before } \\ \text { Installation }\end{array} & \begin{array}{c}\text { After } \\ \text { Installation }\end{array} & \text { Reduce } \\ \text { Repacking } & 6 & 6 & 0 \\ \text { Loading } & 2 & 2 & 0 \\ \text { Unloading } & 10 & 2 & 8 \\ \text { Check/Administration } & 6 & 2 & 4 \\ \text { Load/Unload deliver } & 6 & 6 & 0 \\ \text { Total Worker } & 30 & 18 & 12\end{array}$

Many companies are trying to reduce costs by eliminating manpower with automation technology systems. The very low maintenance costs in addition to the optimization of the available spaces make ASRS the ideal storage solution for the requirements of operational efficiency expressed by the customer.

\section{Space Area}

Table 4Table 4 shows a significant saving of area which can later be used to develop production lines. The data indicates a comparison of data current and after ASRS installation.

Table 4. Comparison before and after

\begin{tabular}{|c|c|c|c|}
\hline & Length & Width & Area \\
\hline Current & $22,620 \mathrm{~mm}$ & $12,190 \mathrm{~mm}$ & $275,737,800 \mathrm{~mm} 2$ \\
\hline Plan & $6,835 \mathrm{~mm}$ & $3,276 \mathrm{~mm}$ & $22,391,460 \mathrm{~mm} 2$ \\
\hline & Saving Space & & $253,346,340 \mathrm{~mm} 2$ \\
\hline & Percentage \% & & $91,90 \%$ \\
\hline
\end{tabular}


Figure 8 indicates the plan of layout for the warehouse if ASRS is implemented replacing current system.

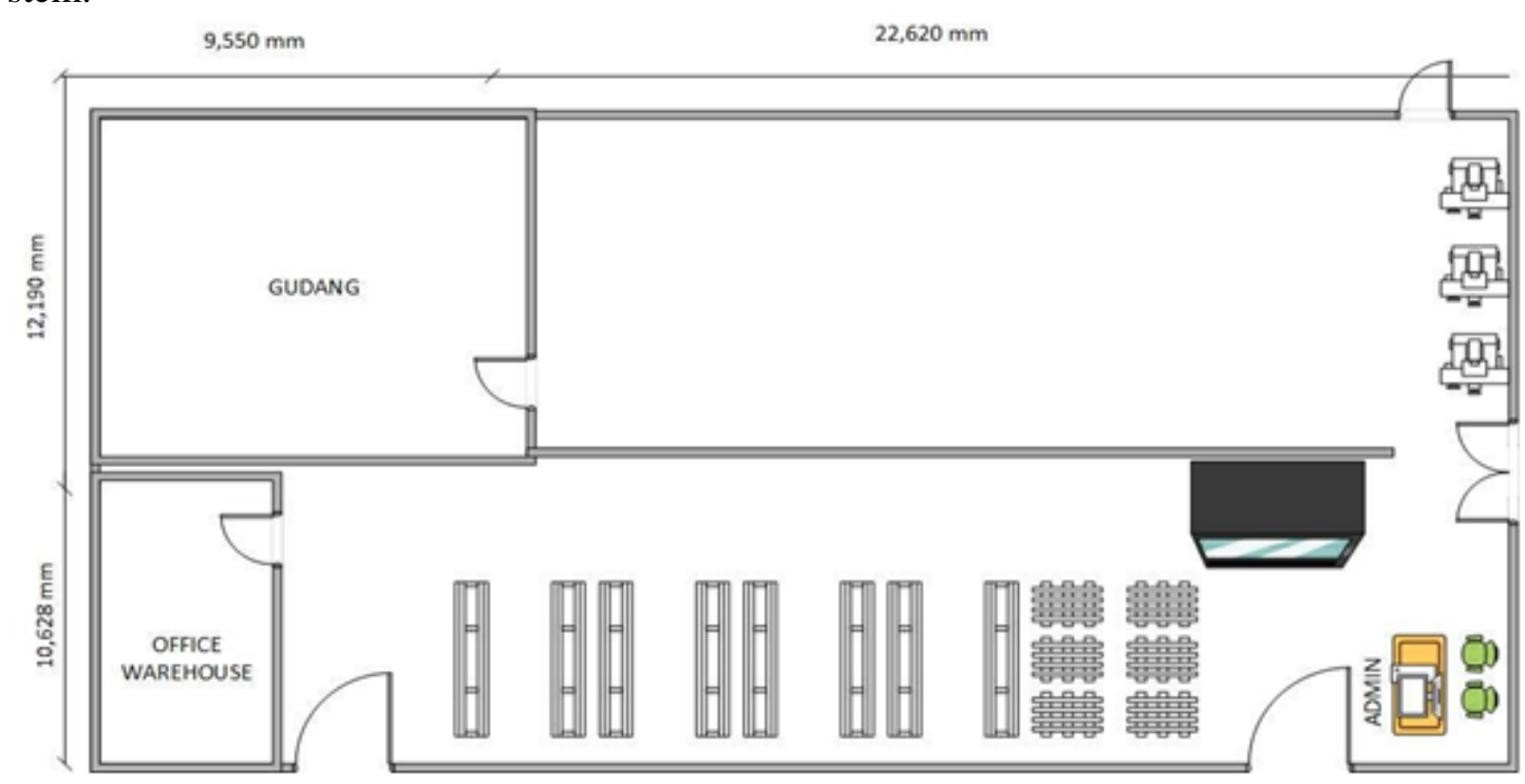

Figure 8. Layout After ASRS Installation

Space, this ASRS has characteristics high rise building and compact needs. So it can afford large number of parts with only little space;

Here are benefit of ASRS for space optimization:

- Eliminate aisles to reduce wasted floor space.

- Store vertically to use wasted overhead space.

- Bring items to user to utilize all available space.

- Reduce wasted space between shelves and items.

- Make use of low and high spaces

\section{Productivity $=$ Workforce Cost - Savings (Picking Activities)}

Order Fulfilment and picking are the most labour- intensive activities and involve significant costs in most warehouses. With the ASRS VLMs, the items are brought automatically to the operators, increasing through-put considerably.

KEY BENEFITS:

a) Goods To Person, Not Person To Goods

b) Easy Identification Of Storage Locations

c) No Walking Of Aisle

d) No Climbing Of Stairs

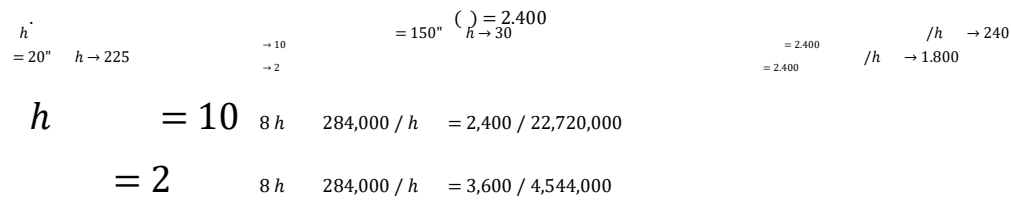




\section{Accuracy $=$ Error Rate Reduction}

The integration of ICONTM, the management software with our ERP, and IRIDE, the innovative multimedia workstation, allow to increase accuracy up to $99 \%$.

Key benefit are:

a) Drastic reduction of picking errors

b) Drastic reduction of refilling errors

c) Reduction of costs related to understock or overstock

d) Error risk reduction thanks to the traceability system and multiple validation.

e) Real time machine monitoring: occupied location, stored materials, movements executed.

f) Highly accurate stock level management through integration with internal ERP systems and a resulting significant reduction in errors during storage and retrieval handling operations.

$$
\begin{aligned}
& \text {. }=3.994 .054 \\
& (\quad)=5,000 \\
& \% \quad(\quad)=1,47 \% \\
& \% \quad(\quad)=0,1 \% \\
& =3.994 .054 \quad 5,000 \quad 1,47 \%=293.562 .947 \\
& =3.994 .054 \quad 5,000 \quad 0,1 \%=19.970 .268 \\
& =\quad 293.562 .947-19.970 .268=273.592 .678
\end{aligned}
$$

\section{Security}

Totally enclosed, lockable and with a special software feature, ASRS VLMs protect goods from unauthorized access and from the every threat. In accordance with the risk control hierarchy theory, various efforts have been made by the company in order to control risk in various activities in the warehouse.

Key benefit are:

a) Protection of stored items from unauthorized access

b) Drastic reduction of thefts

c) Drastic reduction of goods damages

d) Assignment of specific authorizations to single users

e) Fire protection system integration

f) Picking error reduction

\section{Safety System}

The ASRS VLMs access openings are designed to ensure the best ergonomic operationally eliminating the usual necessity of bending, climbing and stretching associated with conventional shelving and rack systems. 


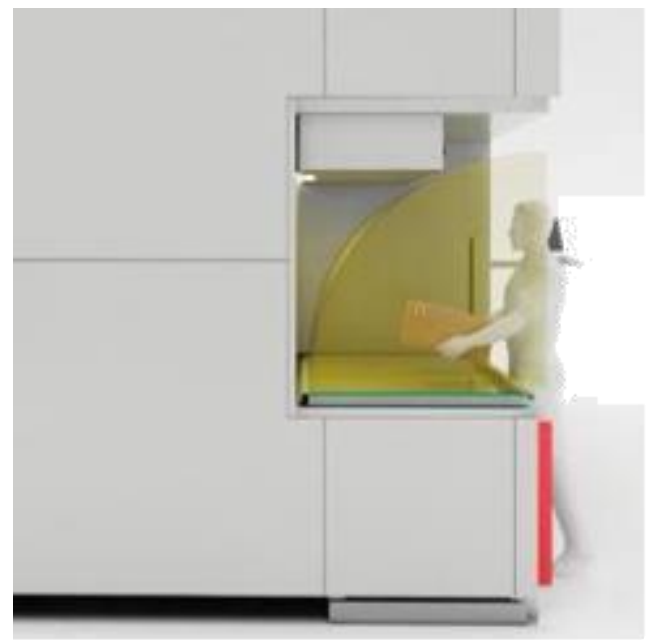

Figure 9. Ergonomic Operationally

Key benefits are:

a) Ergonomics and safety workplace.

b) The operator receives the goods in the access.

c) Opening, at ergonomic height.

d) No climbing stairs/ladders, no risk of falls.

e) No bending/stooping, no risk of muscle strains.

f) Minimize lifting/carrying, no risk of dropping.

g) Reduction of costs related to injuries.

h) A high level of safety and protection for both personnel and the materials stored.

i) Protection of items from theft and fire.

\section{CONTROL (C)}

\section{Standard Operational Procedure}

SOPs are made based on the formulation of causes and causes as well as other factors which plays a role in influencing employee performance. The process was control by continuous monitoring and data collecting. The data used to prove that the solution is valid and able to sustain for long term solution. Time study is taken to make sure the alternative fulfilled some criteria determined.

SOPs are designed to prevent potential work accidents in the warehouse, as well as to support the company's operations in accordance with the company's assumptions. Management also ensures that every SOP point that is made must lead to the achievement of the goals that have been made at the beginning, and remain realistic and efficient when implemented.

\section{CONCLUSION AND RECOMENDATION}

\section{Conclusion}

As a conclusion of this project, it identified that some problems and challenges in the warehouse operation of the company under study are: High Operational cost of warehouse,; Accuracy and security of the systems some parts are loss due to weak in recording of going in and out, it was identified in yearly stock recording; Safety of the warehouse operations are prone accidents in the warehouse operations; and issues of productivity of the current system where the Output vs Input of workers compare to activities. 
In measuring the performance of the current warehouse operations, the study found out that uncontrolled operational cost of the warehouse has reach $\mathrm{Rp} 2,354,400,000 / y e a r$. This number is considered large; It was identified that incorrect items return reach 480 parts in 2020 or approximately

$4 \%$ of the total activities. This may cause customer dissatisfaction and high cost of warehouse; The record of part loss during year 2020 was 1498 unit of part or $0.04 \%$ from the available parts. This is showing the performance of security in terms of item losses per unit of time is alarming; The current warehouse systems prone to accidents. The activities of storing and retrieving of parts are still using the existing equipment. Productivity status of warehouse is low, compare the number of workers in the warehouse reach 30 operators and its operational activities; In terms of cycle time of retrieving parts is indicated 150 second consist of 60 second for putting the parts and 90 second for unloading.

Due to the situation, management need to consider whether to maintain the current system or apply a new warehousing system. Two alternatives were developed, the first alternative was to maintain the current systems with additional warehouse by renting building and additional facilities, the second alternative was suggested to apply an Automated Storage Retrieval System (ASRS). This system applied systems information and application of IoT, where tracking, controlling of parts is much easier.

The team then compare with the performance of the two alternatives. The criteria for selection were developed i.e. Cost; Accuracy, Security, Safety, Productivity, Cycle time, Minimize defect. Using a simple tool in evaluation, it was clear that the second alternative dominate the first alternative. So, the ASRS system was chosen to be implemented.

\section{Recommendation}

In accordance with the theory and analysis results in this case study, various efforts have been made by the company to overcome existing problems starting from risk control to engineering improvement processes in various warehouse activities. However, there are still potential dangers in this area. There are several opportunities to reduce risk after ASRS implementation, including:

1) Should use an arm robot for the pick and place process of material, so that the operator can function as a programmer or maintenance.

2) The use of ASRS needs to be taken into account for areas that have substandard soil strength.

Future challenges:

1) Internet speed in Indonesia is still lacking in running a large system.

2) Cyber security that still doesn't guarantee $100 \%$.

3) Not all locations in Indonesia can use the ASRS system (research needs to be done based on geographic location).

4) A large investment project is needed when doing smart intralogistics.

5) ASRS can be combined with ARM ROBOT and AGV to make fully automatic warehouse.

\section{Refference:}

[1] Azizi, A. A.-H. (2018). Design and Fabrication of Intelligent Material Handling System in Modern Manufacturing with Industry 4.0 Approaches. International Robotics \& Automation Journal, $1-10$.

[2] Bowles, R. (2021, February 26). 4 Essential Warehouse KPIs to Keep an Eye On. Retrieved from LOGIWA: https://www.logiwa.com/blog/warehouse-kpis-key-performance-indicators 
[3] Christopher, M. P. (2003). Marketing Logistics, 2nd edition. Oxford: Butterworth Heinemann.

[4] Coronado, V. (2015, November 13). Optimizing the Warehouse to Maximize Space and Efficacy. Retrieved from Linkedin: https://www.linkedin.com/pulse/optimizing-warehousemaximize-space-efficacy-victor-coronado

[5] Edward H Frazelle, P. (2019). Supply Chain Strategy. Los Angeles: Warehouse Management.

[6] Frazelle, E. (2002). World-class Warehousing and Material Handling. New York: McGrawHill.

[7] Musaoglu, E. (2020, November 17). Unlocking Order Lead Time \& Order Cycle Time Reduction. Retrieved from Logiwa: https://www.logiwa.com/blog/order-lead-time-order-cycle-timereduction

[8] Tadikamalla, P. (1994). The Confusion over Six-Sigma Quality. Quality Progress, pp. 83-85.

[9] Wambua, B. J. (2015). Effects Of Inventory Warehousing System on the Financial Performance of Seventh Day Adventist Institutions. International Journal of Business and Management, 1-14. 